\title{
Towards a New History
}

\section{of European Law}

\section{B ILL DAVIES A N MORTEN RASMUSSEN}

\begin{abstract}
This article introduces the special issue on the new history of European law. Its intention is to provide our audience with the intellectual context that the contributions seek to address and some of the underlying conclusions from the fields of political science and legal scholarship that the archive material synthesised here will recast. Each of the individual contributions will be described and located in the new field of scholarship, and the intentions and current limitations of our findings will be delineated.
\end{abstract}

The European Union is the world's largest economy, home to half a billion Europeans and, despite occasional appearances to the contrary, a powerful influence on its twenty-seven member states. It is also, above all other things, a product and creator of law. The uniquely authoritative European Court of Justice (ECJ) has greatly shaped the development of European integration since the I950s, when the integration process started out as a limited, functional effort to join six national coal and steel industries. The case law of the ECJ has been essential to the creation of something approaching a European legal order - an order that, when compared to international law, is coherent, effective and significantly more influential in the national legal systems than the law that governs a typical international organisation. National courts, in the adjudication of disputes involving citizens, firms and the member states themselves, refer thousands of cases to the ECJ for preliminary rulings each year. This is something long appreciated by legal scholars, of course, and they have later been joined in their analyses by political scientists seeking to explain how this

\footnotetext{
Department of Justice, Law and Society, American University, 4400 Massachusetts Avenue NW, Washington DC 200I6, USA; davies@american.edu

Saxo-instituttet, Københavns Universitet, Njalsgade 80, 2300 København S., Denmark; mortenra@ hum.ku.dk

The authors would like to thank the entire team of contributors for their tremendous work in putting this special issue together. Special thanks must also go to Piers Ludlow, the CEH editor in charge of this theme issue, for his patience as well as the clarity and precision of his immensely useful and necessary work. Finally, we would like to thank the participants of the ARENA research seminar who were instrumental in sharpening the shape and analysis of this introduction.
} 
has come about. Over time, the ECJ, along with many influential commentators, has described the integration process in 'constitutional' terms, with the Court itself serving as the principal defender of a new form of supranational constitutionality over and above the member states.

The conventional story for the emergence of this 'constitutional practice' ${ }^{\text {' }}$ generally begins with two judgments in the early I960s. ${ }^{2}$ The first, the Van Gend en Loos decision of $1963,{ }^{3}$ established the principle of direct effect, recognising that treaty provisions (extended to certain types of secondary rules in later judgments) could enjoy positive legal force directly in national law, if they met certain conditions. Citizens of the member states could, in disputes with their government, argue that a particular national law should not be applied to them because of its nonconformity with European law. In the second, the Costa vs. E.N.E.L decision of $1964,{ }^{4}$ the ECJ dealt with the question of hierarchy between conflicting national and European law, granting the latter primacy. Despite its humble beginnings in the international treaties of Paris (I95I) and of Rome (I957), European law has now not only become the law of the land, but also the supreme law of the land. ${ }^{5}$ Without the acceptance by national courts, these doctrines might have been empty gestures given the striking lack of a constitutional mandate for the ECJ in the original treaties. Over time, however, so the conventional story goes, national judiciaries would come to accept this constitutional practice, if not the full blown claims of European constitutionalism per se, although this process often took decades, and the high courts in particular offered stiff resistance. ${ }^{6}$

It is remarkable that this crucial development of European law - some have provocatively termed it a 'legal coup ${ }^{77}$ - originated in a period of European integration

1 We prefer to call this phenomenon 'constitutional practice' instead of the widely accepted claim that the ECJ actually 'constitutionalised' the treaties. See below for clarification of this choice. The term is taken from J. H. H. Weiler and Ulrich R. Haltern, 'Constitutional or International? The Foundations of the Community Legal Order and the Question of Judicial Kompetenz-Kompetenz', in Anne-Marie Slaughter, Alec Stone Sweet and J. H. H. Weiler, eds, The European Court and National Courts - Doctrines and Jurisprudence: Legal Change in its Social Context (Oxford: Hart Publishing, I998), 33I-65.

2 Only in 1986 did the ECJ dare explicitly to use the term 'constitution' in Parti Ecologiste 'Les Verts' vs. European Parliament. The ECJ judges were conscious about their constitutional interpretation much earlier, see, for example, André Donner, The Role of the Lawyer in the European Communities, The Rosenthal Lectures 1966 (Edinburgh: Edinburgh University Press, I968), I-27.

3 Case 26/62 Van Gend en Loos vs. Nederlandse Administratie der Belastingen [1963] European Court Report I.

4 Case 06/64 Costa vs. ENEL [1964] European Court Report 585.

5 Case II/70 Internationale Handelsgesellschaft vs. Einfuhr- und Vorratsstelle für Getriede und Futtermittel [I970] European Court Report II25.

6 The inter-court dialogue between high courts and the ECJ has certainly not ended, however. A number of national high courts have mobilised against what is regarded as the more sweeping of the ECJ's doctrines, for example, the supremacy of European law over national constitutions. Today, national high courts have assumed the competence to evaluate whether European law undermines national constitutions. These decisions regard the authority of the ECJ as being bound by the national mandate given to it in the original transfer of competences to the European level. Peter Lindseth, Power and Legitimacy, Reconciling Europe and the Nation-State (Oxford: Oxford University Press, 20I0), I33-88.

7 Alec Sweet Stone, 'The Juridical Coup d'Etat and the Problem of Authority', German Law Review, 8 (2007), 916-28. 
$(1962-5)$ that is traditionally characterised by the demise of the federalist ambitions of the European Commission (the Community's supranational executive). These ambitions were personified by Walter Hallstein, the Commission's president, and their demise was reflected in the rise of the member states as the key protagonists in the Community system. ${ }^{8}$ How did the ECJ manage to establish a constitutional practice in the Community in such an environment? Is this a story of heroic selfempowerment in the face of recalcitrant member states - of rescuing the European damsel from the fiery dragons of nationalism and self-interest?

This is certainly the story numerous ECJ judges, writing outside the courtroom, would have us believe. Former ECJ judges and officials have been prolific in justifying their most contentious and far-reaching doctrines by claiming the ECJ simply defended the rule of law against the intrusions of the member states. ${ }^{9}$ Legal scholars and political scientists have found less altruistic motives to explain the remarkable development of European law. They have emphasised the strategic political game played by the ECJ in facilitating the interests of the largest member states, ${ }^{10}$ or the conscious self-empowerment of the ECJ, working in alliance with sub-national actors, such as lower national courts or litigants. ${ }^{11}$ Regardless, the established mainstream account, promoted forcefully by sympathetic academic commentators such as Eric Stein and Joseph Weiler, accepts the basic story promulgated by the ECJ. From this perspective, the ECJ did indeed 'constitutionalise' the Treaties of Rome, creating a European legal order that, measured by most parameters, is similar to that of

${ }^{8}$ See N. Piers Ludlow, The European Community and the Crises of the 1960s (London: Routledge, 2007) for a general treatment of this period in Community history.

9 Robert Lecourt, L'Europe des Juges (Brussels: Bruylant, I976), Pierre Pescatore, 'Aspects judiciaires de l'acquis communautaire', Revue Trimestrielle de droit Europeén, 23 (I98I), 6I7-5I; and Federico Mancini, 'The Making of a Constitution for Europe', Common Market Law Review, 24 (I989), 595-6I4. The Court of Justice, keeping its archive firmly closed, has also been less than willing to co-operate with historians. Harm Schepel and Rein Wesserling have demonstrated that an unusual number of officials have contributed to this policy of deliberate opacity. See Harm Schepel and Rein Wesserling, 'The Legal Community: Judges, Lawyers, Officials and Clerks in the Writing of Europe', European Law Journal, 3, 2 (1997), I65-88.

10 For example Geoffrey Garrett, 'The Politics of Legal Integration in the European Union', International Organisation, 49, I (I995) and Geoffrey Garrett, Daniel R Keleman and Heiner Schulz, 'The European Court of Justice, National Governments and Legal Integration in the European Union', International Organisation, 5, I (1998), I49-76. Andrew Moravcsik, The Choice for Europe: Social Purpose and the State Power from Messina to Maastricht (London: UCL Press, I998).

11 For example Anne-Marie Burley and Walter Mattli, 'Europe before the Court: A Political Theory of Legal Integration', International Organization, 47, I (I993), 4I-76. Walter Mattli and Anne-Marie Slaughter, 'Law and Politics in the European Union: A Reply to Garrett', International Organization, 49, I (I995), I83-90. Walter Mattli and Anne-Marie Slaughter, 'Revisiting the European Court of Justice', International Organisation, 52, I (I998), I77-209. Walter Mattli and Anne-Marie Slaughter, 'The Role of National Courts in the Process of European Integration: According for Judicial Preferences and Constraints', in Slaughter et al., The European Courts and the National Courts, 253-76. Alec Stone Sweet, Governing with Judges: Constitutional Politics in Europe (Oxford: Oxford University Press, 200o). Alec Stone Sweet, 'Path Dependence, Precedent and Judicial Power', in Martin Shapiro and Alex Stone Sweet, eds, On Law, Politics, and Judicialization (Oxford: Oxford University Press, 2002). Karen Alter, Establishing the Supremacy of European Law (Oxford: Oxford University Press, 200I). 
a federal polity. ${ }^{12}$ Although national administrations and high courts occasionally contested this development, the dominant view from this perspective sees a relatively smooth and progressive process of 'constitutionalisation' towards the establishment of a constitutional rule of law in the European Union. Moreover, so the argument goes, this process created a Europeanisation dynamic as the ECJ advanced the cause of 'integration-through-law' by facilitating the move of integration into policy fields hitherto blocked by recalcitrant governments, for example, in the area of equal pay. ${ }^{13}$

This constitutional understanding of integration became completely dominant by the early I990s. However, events surrounding the Maastricht Treaty (which in itself arguably undermined legal unity by adding two new intergovernmental 'pillars' to the new Union) revealed the unwillingness of leading national high courts - most importantly the German Constitutional Court - to subject national constitutions to a supreme European law without the European Union system acquiring equivalent democratic legitimacy to that found in the member states. ${ }^{14}$ The Maastricht Treaty marked the beginning of an ongoing reassessment by legal scholars of the precise character of the integration enterprise. In the following decade the classic constitutional narrative diversified into several alternative versions which, while perhaps adding nuance to the overall picture, also suggested the need for fundamental revision of the historical narrative associated with the classic approach. ${ }^{15}$

Despite further obvious set-backs for the 'constitutional' interpretation (notably the rejection of the Constitutional Treaty of 2005), much of the legal and social science literature today unreflectively analyses integration within some version of the constitutionalisation paradigm and continues to use the classic historical narrative. ${ }^{16}$ A number of dissenting voices, however, have begun to disrupt the settled view. ${ }^{17}$ Morten Rasmussen has argued, for instance, that 'constitutionalisation' fundamentally misrepresents the history of European law and in fact, if carefully scrutinised in historical terms, reveals itself not as a historical fact but as a legitimating strategy promoted by the ECJ itself, along with influential and sympathetic voices in

12 For the classic texts see Eric Stein, 'Lawyers, Judges and the Making of a Transnational Constitution', The American Journal of International Law, 47, I (I98I), I-27, and Joseph Weiler, The Constitution of Europe, (Cambridge: Cambridge University Press, 1999).

13 Mauro Cappelletti, Monica Seccombe and Joseph H. H. Weiler, eds, Integration through Law: Europe and the American Federal Experience, vol. I-V (Berlin and New York: Walter de Gruyter, I986-7). This has spurred an entire literature of political science measuring the impact of the case law of the ECJ on European decision-making and its implementation. For one of the best examples of this literature, consult Lisa Conant, Justice Contained: Law and Politics in the European Union (Ithaca and London: Cornell University Press, 2002).

142 BvR 2134, 2I59/92, Maastricht Decision, I2 October I993 - BVerfGE 89, I55.

15 Matej Avbelj, 'Questioning EU constitutionalisms', German Law Journal, 9, I (2008), I-26.

16 See, for example, a few of the most prominent recent publications in the field, Miguel Maduro, We the Court: The European Court of Justice and the European Economic Constitution (London: Hart Publishing, I998), or Monica Claes, The National Court's Mandate in the European Constitution, (London: Hart Publishing, 2006).

17 See, for example, Niilo Kauppi and Mikael Rask Madsen, 'Institutions et acteurs: rationalité, réflexivité et analyse de l'UE', Politique Européenne, 2, 25 (2008), 87-II3, and Matej Avbelj, 'The Pitfalls of (Comparative) Constitutionalism for European Integration', Eric Stein Working Paper, I (2008). 
the legal academy. ${ }^{18}$ A new Bourdieu-inspired sociology of law has emerged that concomitantly claims that the process of constitutionalisation should be understood as a classic process of judicialisation, through which jurists have managed to empower themselves and multiply their capital through the European construction. ${ }^{19}$ Likewise, Peter Lindseth, a legal scholar with a doctorate in European history, has published a major interdisciplinary synthesis arguing that European integration constitutes a new stage in the rise of the administrative state after the Second World War, in which regulatory power is defused and fragmented 'away from the constituted bodies of representative government at the national level, to an administrative sphere that now operates both within and beyond the state' ${ }^{20}$ In this synthesis, the attempt to establish a constitutional practice by the ECJ extended upon, but also distorted, elements of the 'post-war constitutional settlement of administrative governance', and in this way exacerbated many of the tensions that remain central to the contested legitimacy of the European Union today.

It is time then, to treat the purported 'constitutionalisation' of the European legal order as a historical problématique in need a healthy dose of disciplined analysis based on archival research. In other words, it is time for professional historians to enter a scholarly discussion that, to date, has been dominated by legal scholars and political scientists. Until very recently, the models proposed by legal and social sciences had not been tested against the primary archival sources. ${ }^{21}$ The legal and social science models have largely been based on secondary sources, retrospective interviews, and theories of judicial decision-making developed in other contexts. Only in the last few years, with increasing access to European and national archives, have historians begun to revise the conventional understanding of the ECJ and its role in the integration process. Although our findings and methodology as historians allow us to draw a 'new' and empirically more accurate history of European law, the historical work

18 Morten Rasmussen, 'Constructing and Deconstructing "Constitutional" European Law. Some Reflections on how to Study the History of European Law', in Henning Koch, Karsten HagelSørensen, Ulrich Haltern and Joseph Weiler, eds, Europe: The New Legal Realism, (Århus: DJØF Publishing, 2010), 639-60.

19 Mikael Rask Madsen and Antoine Vauchez, 'European Constitutionalism at the Cradle: Law and Lawyers in the Construction of a European Political Order (I920-I960)', in Alex Jettingholf and Harm Schepel, eds, 'In Lawyers' Circles: Lawyers and European Legal Integration', Recht der Werkelijkheid Tijdsschrift voor de Sociaal-Wetenschappelijke Bestuding van het Recht (2004), I5-34; and Antoine Vauchez, 'The Force of a Weak Field: Law and Lawyers in the Government of the European Union (For a Renewed Research Agenda)', International Political Sociology, 2 (2008), I28-44.

20 Peter Lindseth, Power and Legitimacy: Reconciling Europe and the Nation-State, (Oxford: Oxford University Press, 20IO), 25I.

21 The first important historical contributions were published in the Journal of European Integration History, I4, 2 (2008). A number of important articles, based on archival documentation but with a strong sociological bent and focused on the role of jurists, have been published by the Polilexes research group. For contributions of central empirical importance: Antonin Cohen, 'Constitutionalism without Constitution: Transnational Elites Between Political Mobilization and Legal Expertise in the Making of a Constitution for Europe (I940s-I960s)', Law and Social Inquiry, 32 (2007), I09-35; Julie Bailleux, 'Comment l'Europe vint au droit: Le premier congrès international d'études de la CECA (Milan-Stresa I957)', Revue française de science politique, 60, 2 (2010), 295-3I8; and Antoine Vauchez, 'The Transnational Politics of Judicialization: Van Gend en Loos and the making of EU polity', European Law Journal, I6, I (20I0), I-28, IO-II. 
undertaken for this special issue has undoubtedly been inspired in large part by the fascinating insights provided by the social scientific approaches.

The new history of European law, amply reflected in the articles in this volume, not only challenges the accuracy of many of the models developed to date, but also seeks to redress an imbalance in the existing historiography on integration. Historians of European integration have by and large ignored or underplayed the importance of the ECJ or European law. ${ }^{22}$ The most prominent historians of European integration - Alan S. Milward, Wilfried Loth, Michel Dumoulin, Gérard Bossuat, N. Piers Ludlow and Wolfram Kaiser - have certainly been aware of the Court and its influence, but they have not made it a central object of their analysis. The politics and economics of European integration have, perhaps understandably, dominated the existing historiography. ${ }^{23}$ So law has been the junior partner in the history of the EU, even though, at the same time, national historians have recognised the importance of the law and the judiciary to understanding the last half-century. One only needs to take one example - that of Germany - to see how prolific and contentious national debates about the role of law, justice and the courts have been since Second World War. ${ }^{24}$ This special issue seeks to redress the imbalance in the current historiography by introducing the broader profession to the emerging historical scholarship on European law and its development. As a result of the new archival resources available to historians, this set of articles adds considerable nuance to and in many respects significantly amends the conventional understanding of the legal dimension of European integration as reflected in the work of legal scholars and social scientists.

This special issue provides a broad panorama of the various lines of inquiry currently being pursued by historians. The aim is to shed light on a number of underexplored areas of integration's complex legal history from multiple perspectives - European and national, pre- and post-'coup', thematic and policy areas. While the new history of European law remains a field very much under construction, this special issue will provide its readers with one of the first glimpses into the breadth and depth of the historical work already being undertaken by scholars in this area.

The first article, by Jean-Michel Guieu, explores antecedent debates in the interwar period, which would prove crucial to the emergence of the European legal system in the I950s in the sense of both continuity and rupture. By examining the discourse around the inception of the League of Nations, Guieu shows that the 'universalist'

22 For a recent historiographic assessment see N. Piers Ludlow, 'Governing Europe: Charting the Development of a Supranational Political System', in Wolfram Kaiser and Antonio Varsori, eds, European Union History, Themes and Debates (London: Palgrave MacMillan, 20IO), I22.

23 For a general historiographical overview consult Kaiser and Varsori, European Union.

24 Here, we might point as just one example to the more recent debates created by Ulrich Herbert's Liberalisation-Modernisation-Normalisation thesis, which argues that the economic and political liberalisation of West Germany since 1945 went hand-in-hand with legal reforms promoting gender equality and other liberalisations that aligned West Germany with a general Western/American way of life. Herbert's analysis can be found in: Ulrich Herbert, 'Liberalisierung als Lernprozeß: Die Bundesrepublik in der deutschen Geschichte - eine Skizze', in Ulrich Herbert, ed., Wandlungsprozesse in Westdeutschland: Belastung, Integration, Liberalisierung, 1945-1980 (Göttingen: Wallstein), 7-49. 
hopes for a general and common international legal realm spanning the globe were quickly revealed as overly ambitious. The League of Nations was particularly critiqued by American scholars for its Eurocentric perspective and instead these scholars suggested the creation first of 'continental' legal entities within an overarching global framework. While this idea gained credence in Europe from the mid-I920s and found full expression in the Briand memorandum of I929, European scholars of international law proved unwilling to conceive of European co-operation that went beyond the League framework in legal terms. In legal discussion following the Briand proposal, few were willing to go beyond, for example, co-operation based firmly on unanimous agreement between national governments. While some practitioners in the immediate post-war years supported the establishment of a European federation, the discipline of international law did not change fundamentally in this period. Even confronted with the establishment of the ECSC and EEC, the community of international law scholars continued to argue that these new organisations, although quite complex and original in scope and intention, still remained international organisations based on the consensus between and control of the contracting parties, that is, the states. Confronted with this understanding of the integration venture, one of the ambitions of pro-integration elites in the new European institutions was to transform this mode of thinking and to disseminate the idea that the European institutions were robustly autonomous, held real competences independent from the member states and constituted the first step towards a European federation. Only with this independence could the institutions hope to break from the League of Nations experience and function effectively. However, confronted with reluctant national jurists in the international law community, the attempts to establish an alternative understanding of European law made little headway in the I950s.

The debates over how legally to articulate European integration also quite naturally played a major role in the negotiations of the treaties of Paris (I95I) and Rome (I957) and are analysed by Anne Boerger-De Smedt in the second article. She demonstrates that the negotiators of both the treaties consciously chose not to create a constitutional order, but instead one based on classic international agreements due to the continuing influence of the international law paradigm. Despite this, multiple other legal traditions went into the negotiations over the legal shape of the Communities so that the treaties also contained peculiar features that could later be exploited by the ECJ when seeking to establish a 'constitutional' interpretation of the integration process. As a result, the Court and the legal order that emerged from the negotiations defied easy categorisation. It contained traits drawn from the French administrative law tradition, German ambitions for a constitutional court, Benelux demands for a judicial authority to limit the European executives, and perhaps most importantly, it drew from the new Italian constitutional order the idea of the preliminary ruling mechanism, which would be so central in empowering the European judiciary. These characteristics came about not as part of some grand scheme, but as a result of the work of a small group of federal minded jurists working on the Treaties of Rome, who, shielded by political authorities at appropriate moments, were able to insert provisions with quasi-constitutional character for the 
ECJ and the Legal Service of the Commission to build and establish the subsequent constitutional practice.

The need for new legal models to adapt to the needs of the post-war period also extended to the national arena, as demonstrated in the third contribution. Here Karin Van Leeuwen explores the relationship between national constitutional legal traditions and European integration, which, by focusing on the critically important case of the Netherlands, the member state from which the Van Gend en Loos case would eventually come in $1962-3$, is shown to be both intricate and mutually reinforcing. Van Leeuwen demonstrates that the Dutch constitutional reforms of I953 and I956 drew from many complex sources, not least perceptions of the Dutch national legal tradition and its long-standing openness to international law dating all the way back to the early modern period and the pro-federalist tendencies of some in the Dutch elite. A multitude of national factors were crucial in framing and legitimating the constitutional reforms which in themselves were of central importance to the emergence of the constitutional practice. By instigating reforms to facilitate involvement in the supranational construction, the Dutch were forced to ponder not just the legal nature of European integration, but also questions at the heart of the nature of democratic governance in Europe. The constitutional reforms limited parliamentary involvement in foreign policy, giving more leeway to the executive branch to conclude and ratify treaties in the hope that the loss of democratic oversight nationally would be compensated by increased democratic oversight at the European level. The reforms also gave international law of a self-executing nature primacy in the national realm, a point adopted by the Dutch parliament over the objections of the government. This would prove to be of seminal importance to the future development of European law in the I96os. When the Dutch Hoge Raad, under the influence of several pro-integration judges, ruled that it could not decide on whether European law was self-executing or not - the competence to do so belonged to the ECJ - the floodgates opened for Dutch court referrals to the ECJ on this exact question. Importantly, one of the first of these referrals opened up the possibility for the Van Gend en Loos judgment.

In the fourth article Morten Rasmussen studies the origins of the constitutional practice established by the ECJ in the early I960s. He argues that it was in fact the Legal Service of the European executive that originally developed and promoted the teleological methodology and constitutional interpretation underlying what would later become the constitutional practice. Before I958, the Legal Service did not get very far with its vision, opposed as it was by governments, national and international law jurists and also a conservative ECJ, which seemingly did not want to embark upon a controversial line of case law. After the foundation of the EEC in I958, the Legal Service continued to pursue the same judicial policy. However, to strengthen its hand it helped establish an entire infrastructure of European law by supporting the development of European law associations in all member states and the setting up of an umbrella organisation, the Fédération internationale pour le droit européen (FIDE), at the European level. When the ECJ - after a crucial change in personnel in $1962-3$ was finally ready to embrace the vision promoted by the Legal Service, this 
new infrastructure helped legitimise what the ECJ had done and promote the new doctrines in the member states. The article also carefully untangles the ECJ decisionmaking in the Van Gend en Loos and Costa vs. E.N.E.L. rulings to demonstrate in full detail how a narrow majority of the ECJ embraced the Legal Service interpretation. However, it is also shown how the ECJ did this in a very cautious manner so as to avoid a political backlash. So while the doctrines of direct effect and primacy were introduced, both were interpreted in such a restricted way that the practical consequences of the rulings were negligible for the member states in the short term.

Alexandre Bernier complements the work of Rasmussen by undertaking an archivally based analysis of the French branch of FIDE, the Association des juristes européens (AJE). His aim is to challenge and test the newest developments in social scientific research on the transnational European law associations, which identifies them as a powerful and formative influence on early European law. Tracing the foundation and development of the AJE (I954) in relation to the eventual foundation of FIDE (I96I), Bernier argues that the AJE and then the FIDE did indeed serve a number of important roles in the French and European receptions of the constitutional doctrines. It co-ordinated research agendas and conference topics with the Legal Service, provided supportive academic reviews of ECJ case law, and facilitated meetings of academics, professionals and Community officials to discuss and co-ordinate European law. At the national level, the AJE lobbied national ministries and courts to take European law seriously and then organised national conferences and other public events. Yet - and here is Bernier's new and original contribution - ultimately the AJE, despite its activities, was largely unsuccessful in having a truly positive impact on the French reception of European law. Instead, the broader political context and lack of judicial independence meant that the AJE's early attempts were always destined to fail. In particular, the political reality of post-I958 Gaullist France meant that ambitions of the AJE for the European legal order were always going to be hampered. This was made more acute by the political affiliation of many of the original AJE members with the Fourth Republic, but equally so by Gaullist political control over much of the French judiciary into the I970s. Only once this control loosened could real movement be made by the highest French courts to accept the constitutional practice.

A similar example of how deep-rooted national resistance could be can be found in the sixth contribution, by Bill Davies. Davies explores how European law was received in Germany, demonstrating the extent to which both German media and legal academy had deep concerns about the establishment of the constitutional practice. These concerns focused on the lack of basic rights protection and democratic accountability within the Community. These increasingly loudly articulated apprehensions laid the groundwork for a far-reaching questioning of the 'constitutionalisation' process itself by the highest instance in the German judiciary, the German Constitutional Court. In May I974, the court ruled in its famous Solange $I$ decision that it would retain the final judgment on the primacy of European law as long as a charter of basic rights endorsed by a democratic parliament did not exist at the European level. This was a seminal moment in the establishment of the 
constitutional practice. Davies reveals the secret and public negotiations that occurred between the German government, the Commission and the ECJ in the wake of this resistance. Out of these negotiations came the suggestion by German Advocate General Gerhard Reischl to resolve the crisis by means of a voluntary declaration in which the European institutions would bind themselves to the European Convention on Human Rights. This each European institution ultimately did in a series of steps between 1977 and I979, but only after a lengthy and complicated set of diplomatic negotiations that have never previously been explored. He shows clearly that the Joint Declaration of the European institutions in fact had its origins in the German government's attempt to mollify the explosive legal situation caused by the German Constitutional Court's decision, thus demonstrating that national agency has been as important to the formation of the European legal system as the ECJ itself.

Indeed the last article, by Warlouzet and Witschke, which analyses the role of law and the ECJ in a prominent European public policy area, namely competition policy, demonstrates how similar national forces resisting European integration in the economic field shaped the development of European competition law. Resistance to European-level regulation of competition was strong in most national governments and administrations until the I980s, due to the continued reliance on segmented national markets as a viable economic strategy. While the standard legal and social science interpretation argues that the Commission and ECJ have effectively worked together to expand and empower the European institutions in the field of competition policy, the article demonstrates that even extensive treaty stipulations and increasingly comprehensive case law in this area cannot alone account for the development of an effective European competition policy. In fact, it would take an exceptionally favourable conjunction of economic actors favouring a strong European competition policy from the mid-I980s on, together with the entrepreneurship of members of the Delors Commission, and especially Competition Commissioner Peter Sutherland, to move beyond the existing rudimentary case law successfully to develop a powerful competition policy. Overall, the role of law in this was less decisive and more subtle than previously assumed. The ECJ was certainly not in this case the central 'motor' of integration.

Finally, Peter Lindseth reflects on the overall empirical and theoretical results of the special issue and places them in the larger field of interdisciplinary studies on European legal integration. Substantively, Lindseth views the development of European public law from the perspective of the development of the modern administrative state over the course of the twentieth century. But methodologically, he has long called for opening up theoretical debates over integration to the findings of integration historians. In his view, the emergence of a new historiography on European law is a crucial step forward towards a more empirically refined and a theoretically sounder understanding of the history and nature of European law. His discussion of how these new contributions from historians refine, alter or reject existing explanations and interpretations is consequently of significant importance, serving as a bridge to legal and social science debates in which he has long been steeped. 
Taken as a whole the special issue provides important new historical insights into the origins and development of European law. At one general level the special issue offers a sample of the various dimensions that a full history of European law will have to encompass. It includes - in the first four articles - micro-level studies of institutions and key actors that were instrumental to the creation of the constitutive framework of European law at the national and European level and the establishment of a constitutional practice. It crucially places - as demonstrated by the last three articles the development of European law in a broader context of national and European level social, legal, political and economic actors and structural constraints. The special issue offers two major pieces to the overall puzzle of the history of European law. First, it presents for the first time a comprehensive and fully documented understanding of the complex roots of the establishment of the constitutional practice. These roots were multiple, ranging from the ambiguous nature of the treaties of Paris and Rome and the crucial constitutional revisions of the Netherlands to the determined agency of the Legal Service of the European executive, but also to the change of balance inside the ECJ that proved so decisive to its final acceptance of the constitutional practice. Second, the special issue offers three examples of how the constitutional practice and European law in general were received and what role it played both at the national level and in a major European public policy. What was discovered here was not only how contested the constitutional practice was in key member states such as France and Germany, but also how European law and the ECJ for a long time proved relatively inefficient in an important public policy area such as competition, due to the structural constraints created by the member states' continued national strategies in economic policy. In contrast to the mainstream constitutional paradigm described above, we did not find a relatively smooth process of constitutionalisation leading to a European rule of law, but rather an often overlooked process of historical contestation over the nature of European law by different actors at different times and in different areas. ${ }^{25}$ At the same time it was a process where transnational and European actors, but also national actors, have deeply influenced the development of European law in a complex way that cannot easily be reduced to one single theoretical approach.

What lessons can be drawn by legal scholars and social scientists from these conclusions? First, the notion that European law has somehow been 'constitutionalised' has been revealed historically to be merely the story promulgated by one party in the broader conflict about what the nature of European law should be. That legal scholars and social scientists have developed this notion into a widely accepted truth of integration, which is all-pervasive in current academic discourse on Europe, makes it all the more pertinent to understand the extent to which this notion itself was born as an ideological project and attempt at self-empowerment by the European institutions. We would therefore recommend the use of 'constitutional practice' to describe more accurately the attempt to create a constitutional European

25 In this sense the articles here go beyond the seminal study by Karen Alter which emphasised the contested nature of the same process but focused more narrowly on dialogue between the ECJ and national courts. Alter, Establishing the Supremacy of European Law. 
legal order, also because the continuation of national resistance to the present day makes it very uncertain to what extent the ECJ and the Commission have been successful in their endeavour of fully 'constitutionalising' European law.

Second, the historical insights here identify key agencies as well as structural constraints in explaining the manner in which European law has developed. In terms of agency, the special issue firmly suggests that we need to look beyond courts to understand the development of European law. Not only did the Legal Service of the European Commission play a key role, but transnationally organised European law associations and academics in general also contributed in differing ways to the direction taken by European law. Importantly a whole host of national actors, including governments, administrators, courts, national legal elites, and economic actors contributed to the development of the European system. Finally, some contributions here as well as other research point to the fact that public opinion and media debates also played a hitherto ignored role in the legal history. ${ }^{26}$ This is an avenue of great potential for future research.

Among the central structural constraints identified was the lack of support among national governments and administrations for something even approaching a European constitution, despite the work of the European law associations and pro-integration elites. Not only was this the case during the negotiations over the treaties, but the resistance continued well into the I960s, I970s and I980s. Clearly the resistance demonstrated in France, the Netherlands and beyond during the more recent constitutional debates was not without precedent. Until the work undertaken here, however, these precedents were less than well known. In the battle of ideas, another key constraint was the inertia in the national legal academies in moving to accept the new and original nature of 'supranational' European law. In many cases, the majority of academics continued to view the European treaties and institutions through the standard prism of international law and convincing them that the law and treaties of the Community could have direct effect and primacy in the national realm was (and is) a continual struggle.

The special issue also makes some important historiographical contributions. On the one hand, it provides a transnational history of how European institutions, driven by federalist ideology and a tendency towards self-empowerment, attempted and finally succeeded in establishing a constitutional practice of European law. In this way, the special issue contributes to the growing body of explicitly transnational studies in the field of EU history, which have continually refined our understanding of how multiple and complex forces drive European integration beyond the interests of the member-state governments. ${ }^{27}$ On the other hand, the special issue also offers

26 Bill Davies, Resisting the European Court of Justice: Germany's Confrontation with European Law 1949-1979 (New York: Cambridge University Press, 20I2), especially Chapter 3.

27 Wolfram Kaiser, Brigitte Leucht and Morten Rasmussen, eds, The History of the European Union: Origins of a Trans- and Supranational Polity 1950-1972 (London: Routledge, 2009), first advanced the idea of studying the history of European integration as the emergence of a political system and transnational society. It is important to underline that the approach is open-ended and does not predict any specific or even recognisable final shape to the European polity. 
important complexity to this new school of transnational history. The contestation over the establishment of a European constitutional practice in European law ran deep in the member states, whether in the state administrations, the judiciaries and national legal professions or in public opinion. National responses to the development of European law reflected both the international and European challenges of the postwar era, and also reflected the much older and deeper-lying national legal traditions and preferences. National responses would very much shape the development of European law, blocking or resisting developments at the European level such as competition policy before the I980s. Occasionally national reforms and court rulings - such as Dutch constitutional changes and the Solange I ruling - would constitute profoundly constitutive force on the nature of European law. This adds major nuance to the assumption that transnational historical perspectives can stand alone. Rather, while the exploration of the transnational is an important corrective to the predominance of national histories, it remains a corrective; it needs - as in the case of the history of European law - to be woven into the complexity of thorough stand-alone and comparative studies of the national context. ${ }^{28}$

The special issue has tried to build bridges between the disparate disciplines of History and Law. There is an understandable trepidation on the part of historians to take on the challenge of writing legal history, with its technical nuances seemingly written in a different language. In this particular case, the cases were indeed often concluded in a foreign language! Yet it is important for historians to not underestimate or underplay the importance of law and constitutionalism in the post-war European settlement. This is obviously true for the national systems where the sanctity of the rule of law has become a central part of the democratic fabric of the European states both internally and internationally. But it is also highly relevant in the case of the process of European integration, which was considered and construed in a constitutional and legal form by central actors such as Hallstein. Overall this special issue recommends a more nuanced and perhaps moderate understanding of the role of law in the European construction than mainstream legal and social science, which tends to consider law the very essence of integration. This does not diminish the reality that the creation of a European legal order has strengthened the European institutions in important ways and facilitated and legitimised their endeavour to integrate the member states. For historians to continue to neglect a part of the history of European integration, which is so finely interwoven into almost all dimensions of integration, would seriously endanger our general understanding of the overall phenomenon. The authors believe that the important explanatory power provided by historical analysis is crucial for better understanding the institutions that govern

28 In this sense the major work done by Alan Milward on the socio-economic and political roots of European integration in the nation-state is still as relevant today as it was twenty years ago. See in particular Alan Milward, The European Rescue of the Nation-State, (London: Routledge, I992) and Alan Milward et al. (eds), The Frontier of National Sovereignty, (London: Routledge, I993). For a short introduction to his work on the history of European integration consult Morten Rasmussen, 'European Rescue of the Nation-State? Tracing the Role of Economics and Business', in Kaiser and Varsori, European Union History, I28-49. 
our lives, how they came to be and how we might make more informed, more democratically conscious decisions in our public lives.

While the authors of this special issue are pleased to contribute to this new field, they concede that this is just the first step in revising and recasting the history of European law. Much remains to be done. The newly emerging sources show that the establishment of a constitutional practice was much more complicated than we have previously imagined. Gaining a full picture of the development of European law requires skills, expertise and capacity beyond even the most prolific single academic. This special issue, we hope, will prompt further research and collaboration in this important, interesting and as yet still profoundly underdeveloped historical field.

\section{Vers une nouvelle histoire du droit Européen}

Cet article présente un numéro spécial dédié à la nouvelle histoire du droit Européen. Il offre une description du contexte intellectuel examiné dans plusieurs des articles, ainsi que quelques-unes des conclusions sous-jacentes, tirées des domaines de la science politique et du droit, qui sont remises en cause à la lumière des documents d'archives presentés ici. En décrivant chaque contribution et en la situant dans ce nouveau domaine scientifique, nous espérons tracer les intentions de nos recherches et les contours de nos constatations.

\section{Gen eine neue Geschichte des europäischen Rechts}

Dieser Artikel führt ein in die Sonderausgabe über die neue Geschichte des europäischen Rechts. Er vermittelt unseren Lesern und Leserinnen den in den Beiträgen thematisierten Kontext und einige der zugrunde liegenden Schlussfolgerungen in der Politik- und der Rechtswissenschaft, die das hierin zusammengefasste Archivmaterial in neuer Gestalt darstellen möchte. Jeder einzelne Beitrag wird in dem neuen Wissenschaftsgebiet beschrieben und verankert, und es wird eingegangen auf die Absichten und gegenwärtige Einschränkungen unserer Untersuchungsergebnisse. 